\title{
Theatrum cometicum Stanisława Lubienieckiego młodszego jako przykład zainteresowań astronomiczno-astrologicznych arian
}

\author{
Theatrum cometicum by Stanisław Lubieniecki the Younger as an Example \\ of Astronomical-Astrological Interests of Arians
}

\section{STRESZCZENIE}

Bracia Polscy nazwani "arianami”, „antytrynitarzami” bądź „socynianami” wyodrębnili się w latach 1562-1565 jako tzw. zbór mniejszy z Kościoła ewangelicko-reformowanego (kalwińskiego). Ich największym centrum kulturalnym był Raków. To tutaj w 1602 r. założono słynną Akademię Rakowska, która funkcjonowała do 1638 r. Rakowscy studenci pobierali naukę z zakresu łaciny, etyki, retoryki, matematyki, polityki i nauk przyrodniczych (m.in. zgłębiali tajniki kosmologii). Jednym z najwybitniejszych przedstawicieli Akademii Rakowskiej był Stanisław Lubieniecki młodszy. Napisał niezwykle ciekawą i wartościową poznawczo, acz przez lata niedocenianą pracę o kometach - Theatrum cometicum, części 1-3 (1666-1668), w której opisał aż 415 komet, jakie odnotowano, począwszy od biblijnej epoki potopu po rok 1665. Dzieło to odzwierciedla również poglądy Lubienieckiego na tzw. determinizm kometarny, który nierzadko mu przypisywano. To właśnie dzięki tej wyjątkowej "trylogii” Stanisław Lubieniecki młodszy zasłużył na miano „astronoma”, pomimo że wykształcenia astronomicznego nigdy nie uzyskał.

Słowa kluczowe: arianie, astronomia, astrologia, komety, determinizm

Potępienie twórców nowożytnej astronomii, ze sztandarowym dziełem Mikołaja Kopernika (1473-1543) na czele', stało się przyczyną znacznej, jak to ujął Tadeusz Przypkowski, „schematyzacji” wykładów astro-

${ }^{1}$ M. Kopernik, Dzieła wszystkie, t. 2: O obrotach, tłum. M. Brożek, S. Oświęcimski, kom. A. Birkenmajer, J. Dobrzycki, red. J. Dobrzycki, Warszawa-Kraków 1976; J. North, Historia astronomii i kosmologii, tłum. T. Dworak, Katowice 1997, s. 195-202; A. Koestler, Lunatycy. Historia zmiennych pogladów człowieka na wszechświat, tłum. T. Bieroń, Poznań 2002, s. 119-183, 187-215; J. Wasiutyński, Kopernik. Twórca nowego nieba, Toruń 2007. 
nomii w początkach XVII w. na Uniwersytecie Krakowskim - kolebce nauk matematyczno-astronomicznych (i - dodajmy - astrologicznych) ${ }^{2}$. Niewiele dały starania profesorów Jana Brożka (1585-1652) i Stanisława Pudłowskiego (1597-1645), którzy podejmowali coraz to nowe wyzwania naukowo-dydaktyczne, zmierzające do ożywienia rozwoju tych nauk (choć trzeba podkreślić, iż Stanisław Pudłowski astronomii na Uniwersytecie Krakowskim nigdy nie wykładał) ${ }^{3}$. W związku z zaistniałą sytuacją i nie bez udziału Kościoła, zachowującego daleko posuniętą ostrożność i raczej wrogo nastawionego do wszelkich nowatorskich, burzących dotychczasową wizję świata, odkryć naukowych, znaczenia zaczęły nabierać inne ośrodki badawcze, dotychczas funkcjonujące w cieniu statecznej i wiekowej uczelni krakowskiej. „Katolicki zakaz wykładania heliocentryzmu" ${ }^{4}$ spowodował, że rozwój badań astronomicznych nabrał rozpędu w niekatolickich ośrodkach naukowych (choć i tutaj nie brakowało przeciwników teorii Mikołaja Kopernika) $)^{5}$. Na czoło zaczęło wysuwać się prowadzące wymianę nie tylko myśli, ale również kadry na-

${ }^{2}$ The Reception of Copernicus' Heliocentric Theory. Proceedings of a Symposium Organized by the Nicolas Copernicus Committee of the International Union of the History and Philosophy of Science, Toruń, Poland 1973, ed. J. Dobrzycki, Boston 1973 (Studia Copernicana 5); S. Cynarski, Znajomość nauki Kopernika w Polsce XVII i XVIII wieku, Kraków 1973.

${ }^{3}$ J. Dobrzycki, M. Markowski, T. Przypkowski, Historia astronomii w Polsce, t. 1, red. E. Rybka, Wrocław-Warszawa-Kraków-Gdańsk 1975, s. 240, 241. O wspomnianych profesorach i uczonych por.: J.N. Franke, Jan Brożek (J. Broscius) akademik krakowski 1585-1652. Jego życie i dzieła, ze szczególnem uwzzlędnieniem prac matematycznych. Ze źródeł rękopiśmiennych, Kraków 1884; J. Brożek, Wybór pism, t. 1-2, oprac. H. Barycz (t. 1), J. Dianni (t. 2), Warszawa 1956; H. Barycz, Jan Brożek na tle walki elementów postępowych z tradycyjnymi na Uniwersytecie Krakowskim, Kraków 1954; T. Przypkowski, Zagadnienia astronomiczne w autografach Stanisława Pudłowskiego, „Studia i Materiały z Dziejów Nauki Polskiej”. Seria C. Historia nauk matematycznych, fizyko-chemicznych i geologiczno-geograficznych 1967, 12, s. 261.

${ }^{4}$ J. Dobrzycki, M. Markowski, T. Przypkowski, op. cit., s. 245. Zob. także nadal aktualny w swej treści: A. Nowicki, Kościót przeciwko Kopernikowi, „Myśl Filozoficzna” 1953, 1, s. 209-229; B. Nadolski (Walka o myśl Kopernika i losy jej w Polsce, w: Wkład Polaków do nauki. Nauki ściste. Wybór artykułów, wybór, oprac., przedm. J. Hurwic, Warszawa 1967, s. 37), podkreśla, że w Polsce na uniwersytetach (choć jedynie katolickich) myśl Kopernika po raz ostatni wykładano w 1621 r. Zob. też A. Koestler, op. cit., s. 353-355.

${ }^{5}$ Oponentem Kopernika był protestant Andreas Osiander (1498-1552), który w dziele De revolutionibus orbium coelestium wydawanym w Norymberdze, pod nieobecność patronującego przedsięwzięciu Joachima Retyka, nie tylko zmodyfikował tytuł z De revolutionibus na De revolutionibus orbium coelestium, ale także usunął przedmowę Mikołaja Kopernika, a zamieścił własna, lecz niepodpisaną. $W$ tejże przedmowie wyjaśniał, że teorię heliocentryczną należy rozpatrywać tylko jako hipotezę, wprawdzie pomocną w rozmaitych obliczeniach, jednak nie do końca wiarygodną. Zob. Ł. Barański, bp M. Hintz, J. Sojka, Reformatorzy, Bielsko-Biała 2013, s. 106-107. 
ukowej z uniwersytetem w Królewcu ${ }^{6}$ słynne Gimnazjum Akademickie w Gdańsku, w którym ważnymi postaciami byli: urodzony w Królewcu, a mieszkający w Gdańsku i wykładający astronomię w tamtejszym gimnazjum Piotr Krüger (1580-1639), ponadto Wawrzyniec Eichstadt (15961660), Jan Hecker (1625-1675) i Adam Kochański (1631-1700); w Gdańsku działał również Jan Heweliusz (1617-1687) - najwybitniejszy polski astronom XVII w. ${ }^{7}$. Znaczenia nabrało gimnazjum w Elblągu, ponoć znacznie bardziej tolerancyjne niż gdańskie. To właśnie do tej placówki w połowie XVII w. chętnie przybywali arianie; $\mathrm{z}$ tego też względu przeniósł się tutaj z Gdańska Henryk Nicolai (1605-1660), podejmujący rozważania nie tylko filozoficzno-religijne, ale również astronomiczno-astrologiczne $)^{8}$. Znaczenia nabierało gimnazjum w Toruniu, gdzie jednym z rektorów gimnazjum był zwolennik heliocentryzmu oraz realizmu kartezjuszowskiego Henryk Schaeve (1624-1661), który zgłębiał zagadnienia astronomiczne i kosmologiczne, ale stanowczo odrzucał determinizm astralny ${ }^{9}$, jak również gimnazjum w Lesznie, gdzie wykładano poglądy Galileusza (1564-1642), Kartezjusza (1596-1650), Franciszka Bacona (1561-1626), kształcąc na podstawie ich dzieł znakomitą kadrę naukową - Macieja Głoskowskiego (ok. 1590-1658) oraz Andrzeja Węgierskiego ${ }^{10}$. I wreszcie jednym z najważniej-

${ }^{6}$ K. Ławrynowicz, Albertina. Szkice z dziejów Uniwersytetu Królewieckiego, wstęp Z. Pietrzyk, tłum. J. Leszczyńska, Kraków-Pułtusk 2010.

${ }^{7}$ Zob.: J. Dobrzycki, M. Markowski, T. Przypkowski, op. cit., s. 287-292; Ksiega wpisów Gimnazjum Gdańskiego (1580-1814), oprac. Z. Nowak, P. Szafran, Warszawa 1974, s. 105 (wpis Heweliusza); K. Kubik, L. Mokrzecki, Trzy wieki nauki gdańskiej. Szkice z dziejów od XVI do XVIII w., Wrocław-Gdańsk 1976; Filozofia i myśl społeczna XVII wieku, cz. 2, wybór, oprac. i wstęp Z. Ogonowski, Warszawa 1979, s. 168-175; M. Brodnicki, Program edukacji przyrodniczej w okresie pobytu Jana Heweliusza w Athenae Gedanenses, w: Jan Heweliusz i kultura heweliuszowska. Utilitas et delectatio, Gdańsk 2013, s. 43-52.

${ }^{8}$ T. Przypkowski, Zainteresowania matematyczno-astronomiczne Braci Polskich, w: Studia nad arianizmem, red. L. Chmaj, Warszawa 1959, s. 406; Filozofia i myśl społeczna w Polsce XVII wieku, s. 205-225; B. Bieńkowska, Kopernik i heliocentryzm w polskiej kulturze umysłowej do końca XVIII w., Wrocław 1971 (Studia Copernicana 3), s. 165-170.

${ }^{9}$ Zob. M. Iłowiecki, Dzieje nauki polskiej, Warszawa 1981, s. 67. Por.: H. Barycz, Barok, w: Historia nauki polskiej, t. 2, wstęp, red. B. Suchodolski, Wrocław-Warszawa-Kraków 1970, s. 69-72; S. Tync, Dzieje gimnazjum toruńskiego, cz. 1-2, Toruń 1927-1949; Filozofia i myśl społeczna XVII wieku, s. 233-242; S. Salmonowicz, Nauczanie filozofii w toruńskim gimnazjum akademickim (1568-1793). Organizacja, wykładowcy, podręczniki, w: Nauczanie filozofii w Polsce w XV-XVIII wieku. Zbiór studiów, red. L. Szczucki, Wrocław 1978, s. 137-193.

${ }^{10}$ Gimnazjum w Lesznie okres świetności przeżywało w latach 1626-1655, tj. do najazdu szwedzkiego, kiedy zostało całkowicie zniszczone. Zob. M. Iłowiecki, op. cit., s. 67. Por.: H. Barycz, Barok, s. 77-79; K. Leśniak, Poglądy naukowe Franciszka Bacona, „Kwartalnik Historii Nauki i Techniki" 1961, 6, 3, s. 383-391; J. North, op. cit., s. 222-233; D.K. Yeomans, Komety. Od starożytności do wspótczesności, w mitach, legendach i nauce, tłum. A.S. Pilski, Warszawa 1999, s. 58-62. 
szych ośrodków naukowych w Polsce początku XVII w. stała się powołana do życia w 1602 r. Akademia Rakowska, która sprawiła, że przez wiele lat Raków „stanowił wizytówkę Rzeczypospolitej na zewnątrz"11. Barbara Bieńkowska słusznie zauważa, iż choć przynależność wyznaniowa nie determinowała poziomu nauczania i poglądów naukowych, to jednak w XVII w. środowisko protestanckie zdecydowanie mniej krępowało swobodę badań naukowych ${ }^{12}$. Akademia Rakowska, dzięki wysokiemu poziomowi nauczania, stała się międzynarodowym ośrodkiem szkolnym przyciągającym wybitnych uczonych z Niemiec, Francji, Anglii czy Niderlandów ${ }^{13}$. Podług opinii Wacława Urbana Raków w tym czasie był „religijno-kulturalnym centrum o znaczeniu światowym. W nim przemieszkiwali najczęściej intelektualiści ariańscy. [...] Do Rakowa pielgrzymowali poszukiwacze prawdy i wiedzy z różnych stron", a wszystko z tej przyczyny, iż „Bracia polscy zyskali sobie swą działalnością religijna, filozoficzną i w ogóle kulturalną rozgłos w całym ówczesnym świecie. Utrzymywali kontakty $\mathrm{z}$ najbardziej postępowymi uczonymi swoich czasów $[\ldots]^{\prime \prime 14}$.

Program nauczania w Akademii Rakowskiej obejmował szeroko pojmowane nauki humanistyczne, przyrodnicze (pod tym terminem rozumiano naukę o makrokosmosie, wszechświecie, a więc o przyrodzie ożywionej, człowieku, roślinach, zwierzętach, jak również chemię, fizykę, geologię i astronomię) oraz matematyczne, co wyróżniało placówkę, zwaną „Atenami Rakowskimi”, na tle ówczesnych ordynacji szkolnych nie tylko polskich, ale i europejskich. Na uwagę zasługują programy nauczania autorstwa Marcina Ruara (1589-1657) i Joachima Pastoriusa (1611-1681), które cytowane były przez rektora szkoły, wybitnego matematyka - Joachima Stegmanna starszego (1595-1633) w przedmowie do podręcznika do nauczania arytmetyki i geometrii Institutionum mathematicarum

${ }^{11}$ J. Tazbir, Reformacja w Polsce. Szkice o ludziach $i$ doktrynie, Warszawa 1993, s. 175.

${ }^{12}$ B. Bieńkowska, op. cit., s. 73.

${ }^{13}$ Janusz Tazbir (Ideologia arian polskich, Warszawa 1956, s. 37-38) podkreśla rozwój nauk ścisłych w Akademii Rakowskiej. Szerzej zob.: S. Tync, Wyższa szkoła braci polskich w Rakowie. Zarys jej dziejów (1602-1638), w: Studia nad arianizmem, s. 331-390; idem, Zarys dziejów wyższej szkoły braci polskich w Rakowie, w: Raków ognisko arianizmu, red. S. Cynarski, Kraków 1968, s. 82-172; H. Barycz, Barok, s. 75-76. Bracia Polscy jeszcze przed powstaniem Akademii Rakowskiej przejawiali zainteresowanie naukami astronomicznymi i obserwacją ciał niebieskich oraz zjawisk przez nie wywoływanych, np. zorzy polarnych, o czym wspomina Tadeusz Przypkowski (Zainteresowania matematyczno-astronomiczne Braci Polskich, w: Studia nad arianizmem, s. 391-423).

${ }^{14}$ W. Urban, Losy Braci polskich od zatożenia Rakowa do wygnania z Polski, w: Et haec facienda, et illa non omittenda. Profesor Wacław Urban w swych dziełach wybranych, red. A. Kądziela, W. Kowalski, J. Muszyńska, Z. Pietrzyk, Warszawa 2012, s. 148. 
libri II, quibus initia I. Arithmeticae, II. Geometriae pro incipientibus dilucide explicantur et ad praxin varie accomodantur z $1630 \mathrm{r} .{ }^{15}$. Tadeusz Przypkowski podkreślał, że Joachim Stegmann był również twórcą wielu przyrządów matematycznych i astronomiczno-pomiarowych, które zachowały się do dziś i można je oglądać w Muzeum im. Przypkowskich w Jędrzejowie ${ }^{16}$, a jego podręcznik ,jest dowodem, że w dziedzinie nauk ścisłych nauczanie osiągnęło $\mathrm{w}$ Rakowie najwyższy poziom w Polsce, że jasnością wykładu i znajomością najnowszych zdobyczy nauki europejskiej przewyższało wszystkie wyższe uczelnie w Polsce" ${ }^{\prime 17}$. Do 1638 r., a więc do chwili zamknięcia, Akademia Rakowska wykształciła wielu wybitnych myślicieli, pośród których należy wymienić chociażby filozofa i teologa Andrzeja Wiszowatego (1608-1678) ${ }^{18}$ oraz pisarza politycznego i poetę Samuela Przypkowskiego (ok. 1592-1670) (jeden z jego wierszy zatytułowany Ad aequinoctium autumnale osnuty jest na problematyce kosmologicznej i daje dowód znajomości mitologii kosmologicznej) ${ }^{19}$, jak również pobierających tu nauki przedstawicieli sławnych rodów Morsztynów, Moskorzowskich, Szlichtyngów, Sienieńskich oraz Lubienieckich ${ }^{20}$.

${ }_{15}$ T. Żebrawski, Bibliografija (sic!) piśmiennictwa polskiego z działu matematyki i fizyki oraz ich zastosowań, Kraków 1873, s. 258-260 (nr 885); K. Estreicher, Bibliografia polska, t. 29, Kraków 1933, s. 274. Por. Ł. Kurdybacha, Z dziejów pedagogiki ariańskiej, Warszawa 1958, s. 38-54, 119-129, 130-155.

${ }^{16}$ P.M. Przypkowski, R. Zaczkowski, Zbiory Muzeum im. Przypkowskich w Jędrzejowie, Jędrzejów 2012.

${ }^{17}$ S. Tync, Wyższa szkoła braci polskich, s. 341, 343-344, 355-357, 359. Por. także: idem, Zarys dziejów, s. 98-106; T. Przypkowski, Zainteresowania matematyczno-astronomiczne, s. 398-404, 405. Jednakże J. Tazbir (Stando lubentius moriar. Biografia Stanisława Lubienieckiego, Warszawa 2003, s. 26) uważa, że dyscypliny przyrodnicze i nauki matematyczne traktowano w Akademii Rakowskiej marginesowo, a w programie nauczania znajdowały się one tylko w takim zakresie, jaki wyznaczała ich przydatność w życiu codziennym.

${ }^{18}$ Por.: S. Konarska, Wiszowaty Andrzej, w: Świętokrzyski stownik biograficzny, t. 1: Do 1795 r., Kielce 2002, s. 201-202; L. Chmaj, Bracia Polscy. Ludzie, idee, wptywy, Warszawa 1957, s. 347-407; Z. Ogonowski, Dwa listy Wiszowatego do S. Lubienieckiego, "Studia i Materiały z Dziejów Nauki Polskiej" 1956, 4, s. 347, 352.

${ }_{19}$ Por.: L. Chmaj, Samuel Przypkowski na tle pradów religijnych XVII w., Kraków 1927; J.T. Trembecki, Wirydarz poetycki, t. 1, wyd. A. Brückner, Lwów 1910, s. 406-407 (polskie tłumaczenie wiersza Samuela Przypkowskiego wg Zbigniewa Morsztyna w: ibidem, s. 407); J. Pelc, Rola i znaczenie pisarzy ariańskich w literaturze polskiej XVII wieku, w: Wokót dziejów i tradycji arianizmu, red. L. Szczucki, Warszawa 1971, s. 120; M. Wydrych-Gawrylak, Gwiazdarze i horoskopy, słońca, gwiazdy, księżyce oraz akcesoria astronomiczne, czyli staropolskie fascynacje niebieskie, w: Poezja i astronomia, red. B. Burdziej, G. Halkiewicz-Sojak, Toruń 2006, s. 87-99.

${ }^{20}$ Por.: S. Tync, Wyższa szkoła braci polskich, s. 380-385; W. Dworzaczek, Schlichtingowie $w$ Polsce. Szkice genealogiczno-historyczne, Warszawa 1938. O kwestiach kosmologicznych i metafizycznych, poruszanych przez niektórych członków wspólnoty ariańskiej, m.in. 
Jednym z najwybitniejszych i niewątpliwie najbardziej płodnych przedstawicieli Braci Polskich rozmiłowanych w nauce o gwiazdach, pobierającym naukę początkowo właśnie w Akademii Rakowskiej, a następnie, zanim udał się na studia zagraniczne do Francji i Holandii (chodzi głównie o Orlean, Saumur, Angers, Paryż, Amsterdam, Lejdę, a więc ośrodki, do których chętnie przybywali po naukę tzw. różnowiercy), w Kisielinie na Wołyniu, był Stanisław Lubieniecki zwany młodszym (1623$1675)^{21}$, znany przede wszystkim jako autor dzieła Historia Reformationis Polonicae $^{22}$. Ten wybitny uczony, co warte podkreślenia, pomimo że nie był astronomem, napisał jedno z najważniejszych dzieł tego okresu traktujących o astronomii, ze szczególnym uwzględnieniem komet, pt. Theatrum cometicum $^{23}$. Już sam tytuł, co zauważył J. Tazbir, ewidentnie wpisuje się w stylistykę baroku ${ }^{24}$. Trzy części tego dzieła zostały wydane w Amsterdamie w latach 1666-1668 ${ }^{25}$, a więc niemal jednocześnie z monumentalnym dziełem Cometographia Jana Heweliusza, które ukazało się w 1668 r. (Jarosław Włodarczyk uważa, że liczące ponad 1000 stron i 400 ilustracji dzieło Heweliusza prezentowało zdecydowanie wyższy poziom naukowy niż dzieło Lubienieckiego, choć zawierało opis 250, a nie 415 - jak $\mathrm{w}$ Theatrum cometicum - komet ${ }^{26}$.

Hieronima Moskorzowskiego, por. Myśl ariańska w Polsce XVII wieku. Antologia tekstów, wybór, oprac., wstęp i noty Z. Ogonowski, Wrocław-Warszawa-Kraków 1991, s. 499-554.

${ }^{21}$ Por.: J. Tazbir, Lubieniecki Stanisław młodszy, w: PSB 1972, 17, s. 603-607; S. Konarska, Lubieniecki Stanisław młodszy, w: Świętokrzyski słownik biograficzny, t. 1, s. 90-91.

22 Por.: S. Lubieniecki, Historia Reformationis Polonicae, ed. H. Barycz, Varsoviae 1971; Z. Gołaszewski, Bracia polscy, Toruń 2004, s. 231, 269, 273; J. Tazbir, Stanisław Lubieniecki, przywódca ariańskiej emigracji, Warszawa 1961; H. Barycz, Stanisław Lubieniecki jako historyk reformacji, w: Wokół dziejów i tradycji arianizmu, s. 77-94. J. Tazbir, Stando lubentius moriar, s. 36-52; H. Barycz, Barok, s. 20-32. Z. Ogonowski (Racjonalizm w polskiej myśli ariańskiej i jego oddziatywanie na Zachodzie, OiRwP 1956, 1, s. 159-160) podkreśla, że w XVII stuleciu, obok Niderlandów, głównym terenem ekspansji arian były Wyspy Brytyjskie. Zob. też: S. Kot, Oddziaływanie Braci Polskich zwanych socynianami w Anglii, w: idem, Polska złotego wieku a Europa. Studia i szkice, wybór i wstęp H. Barycz, Warszawa 1987, s. 647-692; H. Barycz, Z dziejów polskich wędrówek naukowych za granicę, Wrocław 1969; D. Żołądź-Strzelczyk, Peregrinatio academica. Studia młodzieży polskiej z Korony i Litwy na akademiach i uniwersytetach niemieckich w XVI i 1 pot. XVII wieku, Poznań 1996.

${ }^{23}$ Zob. S. Lubieniecki, Theatrum cometicum, cz. 1-3, Typis Danielis Baccamude, apud Franciscum Cuperum, sumptibus authoris, Amstelodami 1666-1668 (egz. Biblioteki Muzealnej im. Przypkowskich w Jędrzejowie, sygn. S. 199). Por.: J. Tazbir, Stando lubentius moriar, s. 167-181; J. Gadomski, "Theatrum Cometicum" Stanisława Lubienieckiego, „Urania” 1954, 25, 6, s. 165-177; T. Żebrawski, Bibliografija (sic!) piśmiennictwa polskiego, s. 326-327 (nr 1103); K. Estreicher, Bibliografia polska, t. 21: Stólecie XVI-XVIII, Kraków 1906, s. 432-434.

${ }^{24}$ Por. J. Tazbir, Recepcja polskiego przekładu "Relazioni Universali”, ,Kwartalnik Historii Nauki i Techniki" 1990, 35, 2-3, s. 216 (tu przykłady podobnych tytułów).

${ }^{25}$ Wszystkie części mają identyczny frontyspis z datą $1667 \mathrm{r}$.

${ }^{26}$ Por.: J. Włodarczyk, Dodatek: Astronomia w Polsce, w: Historia astronomii, red. M. Ho- 
Jako pierwszą Lubieniecki opublikował część druga, obejmującą 464 strony (nie licząc 8 stron niepaginowanych wstępu i 4 końcowych, zawierających m.in. indeks), zatytułowaną Theatri Cometici pars posterior sive historia cometarum a diluvio ad A.C. 1665. Część ta zawiera opis wszystkich widocznych na niebie komet, jakie odnotowano, poczynając od tytułowego „potopu” (tj. 2312 r. p.n.e.) aż po czasy współczesne autorowi, uwzględniając komety z lat 1664 i 1665. Dwa lata później wyszła część pierwsza pt. Theatri Cometici pars prior Communicationes de cometis 1664 et 1665 cum viris per Europam Cl. habitas i wkrótce część trzecia Theatri Cometici Exitus de significatione cometarum, przy czym różnią się one od części drugiej formą i treścią, bowiem w części pierwszej na 966 stronach (tu również należy dodać niepaginowane 22 strony wstępu) opublikowana została obfita korespondencja Lubienieckiego z „najtęższymi” ówcześnie europejskimi umysłami, dotycząca przede wszystkim zagadnień poruszanych w części drugiej, zaś najkrótsza, bo licząca 78 stron liczbowanych i dodatkowo 6 niepaginowanych zawierających m.in. erratę i wykaz rycin, część trzecia stanowi uzupełnienie poprzednich i traktuje o znaczeniu komet oraz ich wpływie na czyny ludzkie i wydarzenia rozgrywające się na Ziemi. Całość została wzbogacona wyjątkowej urody rycinami (57 w części pierwszej i $24 \mathrm{w}$ drugiej) ilustrującymi bieg poszczególnych komet na tle układu planetarnego, przy czym, co istotne, za podstawę autor przyjął tu układ kopernikowski. W części pierwszej ponadto znajduje się również portret Lubienieckiego, a w części trzeciej - Jana Ernesta Rautensteina (1622-1666), ministra Filipa Wilhelma (1615-1690), księcia neuburskiego. Co do walorów artystycznych rycin, Tadeusz Przypkowski uznał wręcz, że ich dekoracyjność przewyższa nawet poziom artystyczny rycin pochodzących z dzieł samego Heweliusza ${ }^{27}$. Warto tu jednak wspomnieć, iż, jak podaje Karolina Targosz, Heweliusz miał przesłać Lubienieckiemu ryciny dwóch komet, które ten, nieznacznie je zmieniając (np. Pannę - Virgo ubrał w szatę z kołnierzykiem, podczas gdy u Heweliusza

skin, tłum. i wyd. J. Włodarczyk, Warszawa 2007, s. 329; E. Rybka, Heweliusz Jan, w: PSB 1960-1961, 9, s. 492-494; Bibliografia Literatury Polskiej. Nowy Korbut, red. K. Budzyk, Piśmiennictwo staropolskie, cz. 2, oprac. R. Pollak, Warszawa 1964, s. 264-266; H. Barycz, Barok, s. 72-75. Kometografia Heweliusza wielokrotnie jest przywoływana w dziele Lubienieckiego, Theatrum cometicum, cz. 1, passim; cz. 2, s. 429, gdzie m.in. czytamy: „Clarissimum Hevelius Cometographiae suae totus incumbit”. Zob. J. Hevelius, Cometographia, totam naturam cometarum [...] nec non motum eorum summae admirandum, Simon Reiniger, Gedani 1668 (egz. Biblioteka Śląska, Katowice, sygn. St. Dr. 225097 IV).

${ }^{27}$ Por. T. Przypkowski, Zainteresowania matematyczno-astronomiczne, s. 411. J. Tazbir (Stando lubentius moriar, s. 168-169) wymienia malarzy, miedziorytników i sztycharzy, będących autorami wspomnianych rycin. 
była ona obnażona od pasa w dół), zamieścił w Theatrum cometicum ${ }^{28}$. Całość, aczkolwiek wydrukowana u drukarza cieszącego się niezbyt pochlebną opinią z powodu niskiego poziomu swoich usług ${ }^{29}$, prezentuje się imponująco pod względem edytorskim. Nieco do życzenia może pozostawiać układ - konstrukcja pracy, szczególnie części pierwszej, czasami sprawia wrażenie nie do końca przemyślanej. Stanisław Lubieniecki bowiem niejednokrotnie prowadzi bardzo swobodną narrację, pełną licznych, zupełnie niezwiązanych z motywem przewodnim dzieła dygresji, co utrudnia odbiór i tak, ze względu na pojawiającą się nierzadko hermetyczną terminologię, złożonej treści. Jednakże należy podkreślić, że pomimo pewnych niedociągnięć, autorowi udało się wydać monumentalne i wartościowe poznawczo dzieło, będące swego rodzaju kompendium wiadomości na temat komet obserwowanych od starożytności po lata sześćdziesiąte XVII stulecia.

Janusz Tazbir uważa, że to szczególne zainteresowanie Lubienieckiego kometami było nie tylko efektem jego gruntownego, acz w kwestii komet raczej amatorskiego wykształcenia, ale splotło się ono z chęcią wyczytania z nich zapowiedzi pomyślniejszych losów dla przebywających na wygnaniu współbraci. Sprzyjać temu miało pojawienie się w latach 1664 i 1665 aż dwóch „kul ognistych z warkoczem”, o których pisano "Cometes in tota Europa visus"30. Jednakże w kontekście forsowania przez Lubienieckiego opinii o dwojakich skutkach pojawiania się komet, teza ta wymaga zdecydowanie głębszej refleksji. Nie sposób jednak nie zauważyć, że właśnie wspomniane komety, a właściwie ich obserwacje prowadzone przez wielu ówczesnych badaczy (dość wymienić Fryderyka Hermana Hoyera, Jana Heweliusza, Ismaela Bouilliau [1605-1694], Atanazego Kirchera [1601/1602-1680], Alberta Curtza [1600-1671], Otto Guericka [1602-1686], Mikołaja Heinsiusa etc.) w wielu różnych miejscach (doniesienia słano z takich miast, jak Brema, Wiedeń, Ingolstadt, Wenecja, Me-

${ }^{28}$ K. Targosz, Jan Heweliusz uczony - artysta, Wrocław-Warszawa-Kraków-GdańskŁódź 1986, s. 60-61. Zob. S. Lubieniecki, Theatrum cometicum, cz. 1, tablica 53, 59.

${ }^{29}$ Por. J. Tazbir, Stando lubentius moriar, s. 175.

${ }^{30} \mathrm{~S}$. Lubieniecki, Theatrum cometicum, cz. 1, s. 79. J. Tazbir (Stando lubentius moriar, s. 169) pokazuje, że Lubieniecki $\mathrm{w}$ tym względzie miał postępować podobnie do Jana Placentinusa-Kołaczka, przedstawiciela Braci Czeskich. Zob. także L. Chmaj, Jan Placentinus-Kołaczek, nieznany kartezjanin XVII wieku, "Archiwum Historii Filozofii i Myśli Społecznej" 1957, 1, s. 78-80. Podobnego zdania był A. Brückner, Lubieniecki Stanistaw, w: Wielka encyklopedya powszechna ilustrowana, t. 43-44, Warszawa 1910, s. 797. Wydaje się jednak, że w kontekście dosyć stanowczej krytyki astrologicznych przepowiedni teza ta wymaga bardziej dogłębnej weryfikacji. Na temat wspomnianych komet zob.: J. Włodarczyk, Księżyc w nauce XVII wieku. Libracja: od astronomii do astrofizyki, Warszawa 2005, s. 117; J. North, op. cit., s. 247; D.K. Yeomans, op. cit., s. 68-90. 
diolan, Rzym, Trydent, Paryż, Oxford, Norymberga, Lubeka, Wismar, Ratyzbona, Magdeburg, Hamburg, Sztokholm, Helsingør, Królewiec, Warszawa, Wrocław oraz Gdańsk) i będące ich wynikiem dane astronomiczne zajmują ważne miejsce $\mathrm{w}$ korespondencji Lubienieckiego i jego osobistych rozważaniach na temat komet $^{31}$. Należy również przyznać, że obserwowane $w$ tak krótkim odstępie czasu komety bez wątpienia musiały budzić nie tylko zachwyt i ciekawość poznawczą sceptycznych astronomów, ale również - inspirować astrologów wieszczących nadchodzące kataklizmy. Jeden z nich, londyński astrolog John Gadbury (1627-1704) właśnie w 1665 r. opublikował książeczkę De Cometis: or A Discource of the Natures and Effects of Comets ${ }^{32}, \mathrm{w}$ której wyliczał nieszczęścia, jakie moga nastąpić, jeżeli kometa pojawi się po raz pierwszy w jednym $\mathrm{z}$ dwunastu znaków zodiaku. Zgodnie z jego wizją kometa w znaku Barana oznaczała choroby głowy i oczu, szkody dla bogaczy, smutek i kłopoty dla pospólstwa, Byka - choroby i wielkie trzęsienia ziemi, śmierć wielkiego człowieka, szkody dla bydła, gnicie owoców, Bliźniąt - ciężkie choroby dzieci, skłonność mężczyzn do popełniania cudzołóstwa, wiele poronień, potworne wichury, Raka - głód, zarazy, wojny, szarańcze (gąsienice lub inne robactwo), Lwa - robactwo, szczury, szkody dla wielkich dam, wściekliznę psów, niszczenie zboża przez robactwo, Panny - szkody dla kupców, skandale, hańbę i niesławę dla szlachetnych kobiet, Wagi - złodziei, włamywaczy i rozbójników na drogach, niezwykłe upały i zimno, śmierćkróla, Skorpiona - wojny, rebelie, małe plony, Strzelca - kryzys wśród szlachty, Koziorożca - cudzołóstwo i nierządy wśród mężczyzn, prześladowania pobożnych ludzi, Wodnika - zarazę, wojny, śmierć znacznego księcia lub wybitnej kobiety, Ryb - powietrze przesycone cudami, zagładę ryb. Prognozy te nie sprawdziły się zupełnie w przypadku wyżej wspomnianych komet. Kometa z 1664 r. ukazała się bowiem 17 listopada w południowej części Panny, a po raz ostatni widziano ją 20 marca 1665 r. Druga natomiast ukazała się 26-27 marca 1665 r. ponad Koziorożcem. Według Gadbury'ego winny one zapowiadać skandale, prześladowania i cudzołóstwo, a tymczasem na mieszkańców Londynu spadła wówczas epide-

${ }^{31}$ S. Lubieniecki, Theatrum cometicum, cz. 1, passim; cz. 2, s. 440.

${ }^{32}$ Por.: J. Gadbury, De Cometis: or, A Discourse of the Natures and Effects of Comets as they are Philosophically, Historically, and Astrologically Considered, by L. Chapman, London 1665 oraz L. Stephen, S. Lee, Dictionary of National Biography, vol. 20, New York 1889, s. 345-346; S.J. Schechner, Comets, Popular Culture, and the Birth of Modern Cosmology, Princeton-New Jersey 1997, s. 241; D. Defoe, A. Landa, A Journal of the Plague Year, Oxford 1998, s. 256; W.E. Burns, An Age of Wonders. Prodigies, Politics and Providence in England 1657-1727, New York 2002, s. 99-100; J. Cummins, Milton and the Ends of Time, Cambridge 2003, s. 213, 216; A. Geneva, Astrology and the Seventeenth Century Mind. William Lilly and the Language of the Stars, Manchester 1995, s. 221. 
mia dżumy (do końca 1665 r. zmarło tam ponad 90 tys. osób). Obie komety pojawiły się jednak $\mathrm{w}$ znakach, którym nie przypisywano epidemii, chorób czy zarazy ${ }^{33}$. Pomimo nietrafionych prognoz londyńskiego astrologa wszystkie te wydarzenia, jak również pożar Londynu, jaki strawił znaczną część miasta pod koniec 1666 r. i tak uznano za konsekwencję pojawienia się obydwu komet, co sympatyzujący z arianami John Milton (1608-1674) w opublikowanym rok później Raju utraconym przedstawił w malowniczy sposób:
Naprzeciw Szatan stał nieulękniony
I jak kometa płonął, co rozjaśnia
Wielki gwiazdozbiór Wężownika w niebie
Arktycznym, z włosów straszliwy strząsając
Pomór i wojnę $e^{34}$.

Stanisław Lubieniecki, który za sprawą swoich londyńskich korespondentów, dość wspomnieć Henry'ego Oldenburga (1626-1678)35, śledził najnowsze publikacje astronomiczno-astrologiczne, o czym przekonujemy się z lektury Theatrum cometicum, znał też twórczość Gadbury'ego ${ }^{36}$. Dostrzegając najwyraźniej skłonność ludzi do przypisywania tajemniczym zjawiskom przyrodniczym takich właśnie mocy sprawczych, w Theatrum cometicum stanowczo podkreślał, że na Ziemi zachodzi wiele rozmaitych wydarzeń niepoprzedzonych pojawieniem się komety, jak również pojawienie się tego wyjątkowego ciała niebieskiego wielokrotnie nie zwiastowało żadnego doniosłego wydarzenia ${ }^{37}$. Jednakże wiara w wieszcze właściwości komet była wówczas dosyć powszechnie spotykana nawet u tak światłych umysłów, jak choćby Tycho de Brahe (15461601), Jan Kepler (1571-1630), który, cytując za Lubienieckim, twierdził, że: „[...] labem caeli vocat Cometam"38, a nawet u jezuity Jana Baptisty

\footnotetext{
${ }^{33}$ Por. D.K. Yeomans, op. cit., s. 72-73.
}

${ }^{34}$ J. Milton, Raj utracony, tłum. M. Słomczyński, Warszawa 1974, s. 36 (ks. 2, 861-865). Szerzej o zainteresowaniach astrologicznych J. Miltona por.: T.N. Orchard, Milton's Astronomy. The Astronomy of "Paradise Lost", London 1913, passim; H. Zins, Mikołaj Kopernik w angielskiej kulturze umysłowej epoki Szekspira, Wrocław-Warszawa-Kraków-Gdańsk 1972, s. 136-141.

${ }^{35}$ Zob. S. Lubieniecki, Theatrum cometicum, cz. 1, s. 907-913. O korespondencji por. J. Tazbir, Stando lubentius moriar, s. 173.

${ }_{36}$ Zob. S. Lubieniecki, Theatrum cometicum, cz. 1, s. 692-693. Por. S.J. Schechner, Comets, Popular Culture, and the Birth of Modern Cosmology, s. 119.

${ }^{37}$ Zob. S. Lubieniecki, Theatrum cometicum, cz. 1, s. 160; cz. 3, s. 440.

${ }^{38}$ Zob. ibidem, cz. 1, s. 443. Dopiero późniejsze badania Edmunda Halleya (1656-1742) i Izaaca Newtona (1643-1727), który w 1687 r. dowiódł, że komety podlegają tym samym prawom naukowym, co pozostałe ciała niebieskie, spowodowały, że w kręgach nauko- 
Riccioliego (1598-1671) utrzymującego, iż to anioły prowadzą komety. Tej mało naukowej teorii nie omieszkał przytoczyć Lubieniecki w liście do jednego ze współbraci, również czynnie zgłębiającego tajniki wiedzy astronomicznej - Tobiasza Morsztyna (1624-1664), po raz kolejny dając dowód nie tylko naukowego podejścia do zagadnień astronomicznych, ale również gruntownej znajomości tzw. literatury przedmiotu, jaka wówczas była publikowana (informacje zamieścił w formie wypisów z pierwszego spośród trzech tomów dzieła Riccioliego Almagestum novum astronomiam veterem novamque complectens observationibus aliorum et propiis novisque theorematibus problematibus ac tabulis promotam z $1651 \mathrm{r}.)^{39}$.

W korespondencji zawartej w części pierwszej dzieła Lubienieckiego ówcześni badacze nieba (i nie tylko) niezwykle precyzyjnie przytaczali dane pochodzace $\mathrm{z}$ wnikliwie prowadzonych obserwacji wielu komet. Najważniejszymi punktami odniesienia były: „Situs, Motus, Forma, Lumen, Locus, Cauda directio", a wszystko to służyło precyzyjnemu nakreśleniu drogi, jaką przebywa kometa od początku pojawienia się do jej zniknięcia z pola widzenia obserwatorów ${ }^{40}$. Obserwując kometę z 1664 r., odnotowywano precyzyjnie nawet najmniejsze zmiany jej położenia, dość przytoczyć dwie, poczynione w odstępie niespełna tygodnia, obserwacje: „[...] 31 Grudnia 1664. Godzina 11. w nocy. Odległość od Syriusza $31^{\circ} 46$. Od Rigela $10^{\circ}$ 6. Długość 0.30 Bliźniąt. Szerokość połud. 33.6. Ogon nie był widoczny, a niebo było zachmurzone"; i dalej, pod datą 6 stycznia 1665 r.: „[...] około godziny drugiej, odległość od prawego rogu Barana $20^{\circ}$, od Koziorożca $51^{\circ}$, umiejscowiona między zębami prawej Szczęki Wieloryba"; następnie zanotowano, że od 2 lutego kometa zaczęła się stopniowo kurczyć, a jej kolor blednąć ${ }^{41}$. Tego typu szczegółowych danych odnajdujemy bardzo wiele na kartach dzieła Stanisława Lubienieckiego młodszego.

wych zaprzestano doszukiwać się w kometach nadprzyrodzonych mocy. Zob.: A. Marks, Pod znakiem komety, Katowice 1985, s. 29-44; J. North, op. cit., s. 211, 241-268.

${ }^{39}$ S. Lubieniecki, Theatrum cometicum, cz. 1, s. 514, 616. Zob. także T. Przypkowski, Zainteresowania matematyczno-astronomiczne, s. 407-411.

${ }^{40}$ S. Lubieniecki, Theatrum cometicum, cz. 1, s. 210, 709, 711 i nn.

${ }^{41}$ Por.: ibidem, cz. 1, s. 771 („Die 31. Decemb. Hora undecima noctis. Distantia a Sirio $31^{\circ} 46$. A Rigel $10^{\circ} 6$. Longitudo 0.30 Gemin. Latid. Aust. 33.6. Cauda non apparebat et caelum erat opertum”); ibidem, s. 778 („6. Jan. Circa secundam horam. Distabat a dextro cornu Arietis $20^{\circ}$. A Capra $51^{\circ}$. Situs inter dentes Mantibulae dextrae Ceti"). Kometa była zatem obserwowana na tle gwiazdozbiorów Bliźniąt, Barana, Koziorożca i Wieloryba. Podano również jej odległość od Syriusza - najjaśniejszej i jednej z najbliższych gwiazd tzw. nocnego nieba, położonej w gwiazdozbiorze Wielkiego Pasa oraz znajdującej się w gwiazdozbiorze Oriona gwiazdy Rigel - siódmej pod względem jasności gwiazdy na niebie. Zob. ibidem, cz. 1, s. 783. 
Te wnikliwie prowadzone obserwacje miały na celu także zgłębienie natury komet. Theatrum cometicum jest wręcz przepełnione naukowymi, acz bywa, że i pseudonaukowymi dywagacjami mającymi na celu wyjaśnienie fenomenu "ognistych kul z ogonem”, obserwowanych albo gołym okiem („sine instrumentis"), albo przy użyciu „Tubae Opticae" ${ }^{\prime 2}$. Analizowano zatem nie tylko czas i miejsce ich pojawienia się, kierunek i trajektorię przemieszczania (wierzono wówczas, że komety poruszają się po linii prostej, o czym wspominał Lubieniecki, relacjonując poglądy Heweliusza $)^{43}$, ale też moc wysyłanych promieni, długość i zakrzywienie ogona, ponad to ich kształt, uznając, iż może on być okrągły, kwadratowy, spłaszczony, owalny bądź dowolny. Tzw. Excerpta ex Kircheriana Physiologia nova de Cometae stały się dlań jednym ze źródeł wiedzy na ten temat. To stąd zaczerpnięte zostały m.in. informacje, iż materia, $\mathrm{z}$ której zbudowana jest kometa, w sposób widoczny warunkuje jej kolor (określany również jako „światło" - Lumen). Na tej podstawie słusznie stwierdzono, że może on być różnoraki, od bladego po ognisty, na co ma wpływ także pora obserwacji i przejrzystość nieba, szczególnie nocnego ${ }^{44}$. Atanazy Kircher z kolei, jak możemy przypuszczać, sporządził wyciąg interesujących go kwestii z 32-stronicowego dzieła Gioseffa Petrucciego - Fisiologia nuova della natura delle comete, opublikowanego w Rzymie w 1665 r. Co ważne, w listach do Lubienieckiego Kircher wypowiada się niezwykle przychylnie o Petruccim, nazywając go swoim uczniem i wychowankiem („meus privatus Academicus", „meus privatus discipulus" $)^{45}$, co jednocześnie zdaje się być wyraźną aprobata, żeby nie powiedzieć - pochwałą dokonań naukowych młodego Petrucciego.

Niewątpliwie obserwacja zmieniającego się wyglądu komet stanowiła ważny element prowadzonych nieustannie badań naukowych, co potwierdzają zapisy uczonych takowe obserwacje czyniących. I tak słynną kometę z końca 1664 r., w zależności od miejsca obserwacji, 10 grudnia opisywano słowami: „Color Cometae notatus est magis lividus, quam

${ }^{42}$ Ibidem, cz. 1, s. 355.

${ }^{43}$ Ibidem, cz. 1, s. 423-424.

${ }^{44}$ Por. ibidem, cz. 1, s. 758 („Color cometae est varius idque autor dicit provenire a qualitate materiae fumosae; si halitus fumosi se incendunt, subito resplendent colore flammeo; si vero hic ardor successive deficit propter frigus ambiens, eo casu fuscum mutabunt pallore: imo quanto magis hi fumi ascendunt in altum, eo pallidores apparebunt. Medio noctis, quando nimirum aër a vaporibus est purgatus, libere videtur claritas Cometarum, verum quando hi appropinquant horizonti, ubi vicini vapores aërem reddunt crasfiorem, videntur pallidi"). Zob. też J. E. Fletcher, A Study of the Life and Works of Athanasius Kircher, "Germanus Incredibilis". With a Selection of His Unpublished Correspondence and an Annotated Translation of His Autobiography, Leiden 2011, s. 547-548.

${ }^{45}$ S. Lubieniecki, Theatrum cometicum, cz. 1, s. 754-755. 
candidus, et fere luridus”, a 2 dni później odnotowano, iż jej „corpus apparebat pallidum et subalbidum" ${ }^{\prime 6}$. Podobne uwagi na kartach dzieła Lubienieckiego odnajdujemy po wielekroć. Czytamy tu bowiem, iż komety zmieniają kolor w ciągu dnia w zależności od odległości od Ziemi, a tym samym obserwatora, bowiem, im mniejszy dystans, tym będzie się wydawać iż „,rubicundiores, ignei maiores, lucidiores, nobis plerumque sint viciniores" ${ }^{\prime \prime}$.

Ideą przyświecającą Lubienieckiemu, jak się zdaje, była nie tylko rzetelna prezentacja najnowszych badań popartych doświadczeniami czy wiedzy czerpanej od poprzedników. Wzywał on bowiem jednocześnie do podjęcia programowych badań naukowych nad tym zagadkowym fenomenem przyrody, za jaki uważał komety, nazywając je nawet „belissimi ornamenti naturae" ${ }^{\prime 4}$. To właśnie w braku wnikliwych obserwacji upatrywał "fałszowania wiedzy" na temat komet, szczególnie w kontekście fatalistycznego interpretowania ich pojawienia się ${ }^{49}$. Trzeba jednak zauważyć, że nie negował on zupełnie możliwości oddziaływania tych ciał niebieskich na wydarzenia rozgrywające się w świecie podksiężycowym, przy czym prezentował tu nader rozsądne, można powiedzieć - racjonalistyczne stanowisko. Wielokrotnie powtarzał bowiem zdanie, które można uznać za ważną konkluzję tego opasłego dzieła, zgodnie z którą pojawiająca się na firmamencie niebieskim kometa zwiastuje "bona bonis, mala malis" - proporcje zaś pomiędzy pomyślnymi a niepomyślnymi wydarzeniami są wyrównane ${ }^{50}$. Zatem, jak można wywnioskować z wywodów Lubienieckiego, nie ma powodów, by obsesyjnie obawiać się komet! Było to niezwykle nowatorskie, albowiem do tego czasu pojawieniu się komet przypisywano wyłącznie negatywne skutki, nigdy zaś pozytywne.

Takie właśnie podejście do determinizmu kometarnego warunkowały racjonalizm i wiara $\mathrm{w}$ wolną wolę człowieka ${ }^{51}$. Wydaje się, że ma to

${ }^{46}$ Ibidem, cz. 1, s. 2, 766.

${ }^{47}$ Ibidem, cz. 1, s. 721.

${ }^{48}$ Ibidem, cz. 1, s. 416, 341.

${ }^{49}$ Por. ibidem, cz. 3, s. 42 („Experientia saepius fallax est, non quidem in se, sed exploratorum vitio vel observationum difficultate").

${ }^{50}$ Por. ibidem, cz. 1, s. 201-202, 524, 861, 935 i nn.; cz. 3, s. 3, 8, 10, 31, 43, 52 i nn. Zob. J. Dobrzycki, T. Przypkowski, M. Markowski, op. cit., s. 295, gdzie czytamy, że dla Lubienieckiego "boni" to Bracia Polscy, a "mali” to ich wrogowie.

${ }^{51}$ Por.: K. Grycz-Śmiłowski, Bracia Polscy. Arianie - unitarianie. Zarys dziejów i nauki, Kraków 1948, s. 17, 23; Z. Ogonowski, Racjonalizm w polskiej myśli ariańskiej, s. 141-163. Racjonalizm reprezentowany był m.in. przez Kartezjusza, z którym Stanisław Lubieniecki młodszy prowadził dysputy na temat ruchu Ziemi i z którego teoriami natury filozoficznej umiejętnie polemizował. Zob.: S. Lubieniecki, Theatrum cometicum, cz. 1, s. 506-508, 568, 604; J. Włodarczyk, Księżyc w nauce XVII wieku, s. 59, 63; Z. Ogonowski, Socynianizm pol- 
wyraźny związek z ideologią Braci Polskich, zakładającą istnienie pochodzącej od Boga względnie wolnej woli ludzkiej, która wykluczała wiarę w nieuchronne oddziaływanie ciał niebieskich na myśli i czyny ludzkie ${ }^{52}$. W Theatrum cometicum czytamy bowiem, iż nie wolno podawać w wątpliwość wolności woli ludzkiej, bowiem godzi to w praprzyczynę, którą jest „Deus Optimus Maximus" ${ }^{53}$. A wierzenia religijne, jak uważali Bracia Polscy, nie mogły być sprzeczne z osiągnięciami nauki. Stanisław Lubieniecki, człowiek wielkiej wiary i pobożności, wielokrotnie powtarzał, iż wprawdzie może się zdarzyć, że gwiazdy będą kierowały ludźmi, jednakże gwiazdami zawsze kieruje Bóg - Stwórca wszystkiego, co w niebie i na ziemi, którą to myśl w liście do Stanisława Joachim Stegmann młodszy (1618-1678) streścił słowami „Astra regunt homines, sed regit astra Deus ${ }^{\prime \prime 5}$.

Z tego też względu nie powinny dziwić nader rzeczowe sądy na temat oddziaływania ciał niebieskich na tzw. świat podksiężycowy, wydawane przez współbraci Lubienieckiego, m.in. przez wspomnianego Andrzeja Wiszowatego, który w jednym z listów do autora Theatrum cometicum podkreślał, że tylko przyczyny naturalne mogą stanowić wyjaśnienie zjawisk naturalnych obserwowanych na Ziemi, a więc również pojawiających się na niebie komet. Odrzucał tym samym pogląd upatrujący w kometach działania sił nadprzyrodzonych, nadających im moc spraw$\mathrm{cząc}^{55}$, bowiem uważał, że dla wyjaśnienia tego fenomenu nie trzeba się uciekać do zjawisk typu motores externos, a to z tej przyczyny, że sama natura dysponuje odpowiednimi środkami, wprowadzającymi komety w ruch ${ }^{56}$.

ski, Warszawa 1960, s. 56-59; W. Wąsik, Kartezjusz w Polsce, „Przegląd Filozoficzny” 1937, s. 198-240, 414-463; L. Chmaj, Kartezjanizm w Polsce w XVII i XVIII wieku, „Myśl Filozoficzna" 1956, 5, s. 67-102; D.K. Yeomans, op. cit., s. 63-65; P. Hazard, Kryzys świadomości europejskiej 1680-1715, tłum. J. Lalewicz, A. Siemek, wstęp M. Żurowski, Warszawa 1974, s. $146-148$.

${ }^{52}$ Fragment Katechizmu Rakowskiego, dotyczący wolnej woli ludzkiej, zob. Myśl ariańska w Polsce, s. 408-415. Por. Z. Gołaszewski, op. cit., s. 273. Tadeusz Przypkowski (Zainteresowania matematyczno-astronomiczne, s. 413) zauważa, że oprócz katolików wielkim obrońcą astrologii był wówczas przedstawiciel Braci Czeskich Jan Placentinus-Kołaczek, który linię swojej obrony astrologii podpierał wieloma cytatami z Biblii. Zob. Theatrum cometicum, cz. 1, s. 558-559, 563, 569-573. Jan Placentinus-Kołaczek, co warto podkreślić, był uczniem Gimnazjum Gdańskiego oraz Uniwersytetów w Królewcu i Lejdzie, gdzie zgłębiał m.in. nauki Kartezjusza. Por. H. Barycz, Barok, s. 53-54; zob. Filozofia i myśl społeczna w Polsce XVII wieku, s. 226-232.

${ }^{53}$ Theatrum cometicum, cz. 1, s. 613.

${ }^{54}$ Ibidem, cz. 1, s. 605. Cytat ten pojawia się wielokrotnie w dziele Lubienieckiego.

${ }^{55}$ Por. ibidem, cz. 1, s. 610; L. Chmaj, Bracia Polscy, s. 400.

${ }^{56}$ Por. S. Lubieniecki, Theatrum cometicum, cz. 1, s. 610. 
Poglądy te były zbieżne z poglądami Lubienieckiego, co niewątpliwie miało związek z jego nader pozytywnym nastawieniem do teorii heliocentrycznej, na którą powoływał się niejednokrotnie ${ }^{57}$. Solidaryzował się tym samym ze stanowiskiem chociażby Heweliusza, którego wielce cenił. Uznawał go za „znakomitość w astronomii”, a w listach do Ismaela Bouilliau, pisząc o nim, używał określenia „Noster Amicus Amplissimus Hevelio", co, jak się wydaje, nie było tylko przepełnionym stylistyką baroku kurtuazyjnym zwrotem, jakich wiele w dziele, ale wyrazem prawdziwego uznania dla naukowych dokonań mistrza ${ }^{58}$. Jako że część pierwsza Theatrum cometicum opublikowana została w 1668 r., co, przypomnijmy, zbiegło się w czasie z publikacją Kometografii Heweliusza, odnajdujemy $\mathrm{w}$ niej wiele odniesień do tejże ${ }^{59}$. Zdaje się to potwierdzać nie tylko dobre stosunki obydwu uczonych, ale przede wszystkim aktualną wiedzę Lubienieckiego i umiejętność docenienia wartości merytorycznej „konkurencyjnego" dzieła traktującego o historii komet.

Stanisław Lubieniecki, prowadząc nader ożywioną korespondencję zamieszczoną w części pierwszej Theatrum cometicum, oprócz problematyki astronomicznej poruszał wiele rozmaitych kwestii natury filozoficznej, teologicznej, historycznej i ogólnie rzecz ujmując - przyrodniczej. Z listów tych dowiadujemy się wielu ciekawych rzeczy na temat ówczesnych odkryć naukowych. Otto Guerick, słynny badacz właściwości powietrza, w jednym $z$ nich przekazał Lubienieckiemu informacje dotyczące ważnego wynalazku, jakim był barometr ${ }^{60}$. To z nim Lubieniecki prowadził listownie dysputę De eo quod est et quod non est, wplatając w to nie tylko dywagacje natury naukowej, ale również duchowej ${ }^{61}$. Teologiczne i filozoficzne rozważania zajmują dużo miejsca w listach, jakie Stanisław Lubieniecki wymieniał z Joachimem Stegmannem młodszym czy wzmiankowanym Andrzejem Wiszowatym (ten odważnie występował przeciwko Arystotelesowi ${ }^{62}$, przy czym należy podkreślić, że obydwaj uczeni aria-

${ }^{57}$ Por.: T. Przypkowski, Dzieje myśli kopernikowskiej, Warszawa 1954, s. 82; idem, Z dziejów heliocentryzmu w Polsce, „Myśl Filozoficzna” 1953, 1, s. 176-190.

${ }^{58}$ S. Lubieniecki, Theatrum cometicum, cz. 1, s. 260, 396-397, 455, 534, 629. W liście do jezuity Riccioliego (17 V 1665) pisał: „Hevelius (-at quantus in Astronomicis Vir!)” (ibidem, s. 701; na s. 34, czytamy natomiast: „Excellentissimi Astronomii Hevelii”).

${ }^{59}$ Por. ibidem, cz. 1, passim; na s. 361-416 - obszerna korespondencja Lubienieckiego z Heweliuszem.

${ }^{60}$ Por. ibidem, cz. 1, s. 240-241.

${ }^{61}$ Por. ibidem, cz. 1, s. 247.

62 Por. Z. Ogonowski, Dwa listy Wiszowatego do S. Lubienieckiego. O stosunku Wiszowatego do zagadnień kosmologicznych dowiadujemy się z listów do Lubienieckiego, bowiem dzieło Phisicae problema, poruszające te kwestie, zaginęło. Zob.: T. Przypkowski, Za- 
nie prezentują racjonalistyczny stosunek do wszelkich zagadnień kosmologicznych. Atanazy Kircher natomiast przesłał Lubienieckiemu z Rzymu wyniki obserwacji Saturna i Jowisza, jakie w lipcu 1664 r., przy użyciu teleskopu własnej konstrukcji, przeprowadził Józef Campana. To właśnie wtedy po raz pierwszy w literaturze światowej odnotowano rozdział pierścieni Saturna oraz ukazano Jowisza z tajemniczą czerwoną plamą i sylwetkami jego księżyców widocznymi na tle tarczy planety ${ }^{63}$. Warto zauważyć, że Lubienieckiemu, którego uważano powszechnie za „heretyka-emigranta" ${ }^{\prime 4}$, udało się nawiązać owocny kontakt z jezuitami, m.in. wspomnianymi Atanazym Kircherem, Janem Baptystą Ricciolim i wybitnym fizykiem Kasperem Schottem (1608-1666), o których to uczonych pisał: „Celeberrimi Societas Jesu Philosophi Riccioli, Kircherus et Schottus" ${ }^{\prime 65}$, a którzy przesłali mu nawet protokoły obserwacji komet, jakie czyniono wówczas w większości klasztorów jezuickich. Należy tu wymienić także profesora matematyki z Kolonii Samuela Reyhera (1635-1714), profesora matematyki frankfurckiej Viadriny Jana Placentinusa Kołaczka (1630-1683), profesora matematyki na uniwersytecie w Królewcu Andrzeja Conciusa (1628-1682), duńskiego fizyka i matematyka Rasmusa Bartholiniego (1625-1698) oraz asesora króla Danii, profesora matematyki i astronomii Villuma Langego (1624-1682) i wielu, wielu innych, którzy chętnie korespondowali ze Stanisławem Lubienieckim młodszym, dając tym samym dowód akceptacji, żeby nie powiedzieć - docenienia jego starań naukowych na płaszczyźnie nauk matematyczno-astronomicznych ${ }^{66}$.

Swobodna wymiana myśli i dysputy naukowe toczone $\mathrm{z}$ tak wybitnymi postaciami ówczesnego świata nauki świadczą nie tylko o rozległych kontaktach i „lekkości pióra”, ale przede wszystkim właśnie o erudycji Lubienieckiego ${ }^{67}$, który wyjątkowo biegle poruszał się po meandrach wiedzy astronomicznej, dokonując trafnych uogólnień, porównań, powołując się przy tym na najbardziej aktualne wyniki prowadzonych badań, z dumą pisząc: „Hevelio, Bullialdo, Kirchero aliisque conspiriare libenter

interesowania matematyczno-astronomiczne, s. 418; S. Lubieniecki, Theatrum cometicum, cz. 1, s. 610-611.

${ }^{63}$ Por.: ibidem, cz. 1, s. 717, 720, 755, tabl. 18; T. Przypkowski, Pierwsze poprawne widoki Jowisza i Saturna z r. 1664 ogłoszone przez Stanisława Lubienieckiego, „Sprawozdania z Czynności i Posiedzeń Polskiej Akademii Umiejętności" 1951, 52, 6, s. 536.

${ }^{64}$ T. Przypkowski, Zainteresowania matematyczno-astronomiczne, s. 414.

${ }^{65}$ Por. S. Lubieniecki, Theatrum cometicum, cz. 1, s. 288, 402, 761-796.

${ }^{66}$ Por. J. Tazbir, Stando lubentius moriar, s. 170-173.

${ }^{67}$ Por. S. Lubieniecki, Theatrum cometicum, cz. 1, s. 531 (dowód znajomości dzieł Galileusza). 
intelligo" ${ }^{\prime 68}$. Dzięki tak szeroko zakrojonej współpracy udało mu się zestawić i opisać aż 415 komet, co stanowi znakomity punkt odniesienia dla współczesnych badaczy, którzy na tej podstawie mogą uściślać orbity cyklicznie pojawiających się komet, wliczając w to słynną kometę Halleya ${ }^{69}$. Co ważne, konstruując to jakże ważne dzieło, Lubieniecki chętnie korzystał również z wiedzy swoich poprzedników. Odwoływał się do Kamila Marcela Squarcialupiego (zm. 1599), który występował przeciwko przypisywaniu kometom mocy sprawczych ${ }^{70}$ oraz Jana Praetoriusa (1537-1616), wspominając czynione przezeń obserwacje komety z lat $1577-1578^{71}$. Niejednokrotnie powoływał się także na ustalenia uczonych islamskich, uznane autorytety Pisma Świętego, Ojców i Doktorów Kościoła, dość wymienić św. Tomasza z Akwinu, św. Augustyna, św. Tertuliana, oraz na starożytnych filozofów, przywołując Arystotelesa, Sokratesa, Pitagorasa, Senekę, Solona, Plutarcha i Ptolemeusza, raz po raz przytaczając przypisywaną mu od wieków sentencję "Sapiens dominabitur astris"72. Nieobce mu były, co warte podkreślenia, również dzieła stricte astrologiczne (nadal bowiem, pomimo usilnych starań wielu badaczy parających się astronomia zamiennie używano określeń „,astrologia” i „astronomia”), dość wymienić dzieło Juliusa Firmicusa Maternusa De nativitatibus sive Matheseos Libri VIII i wzmiankowane De Cometis... Johna Gadbury'ego, przy czym starał się ich treść interpretować tak, aby zminimalizować oddziaływanie komet na człowieka ${ }^{73}$. I choć odcinał się od determinizmu kometarnego, to jednak konieczne jest odnotowanie licznych wzmianek zdających się sugerować dopuszczanie przez Lubienieckiego oddziaływania innych, niż komety, ciał niebieskich, szczególnie planet i gwiazd na życie w świecie podksiężycowym. Wpływ ten jednak, podług badacza, może dotyczyć

${ }^{68}$ Ibidem, cz. 1, s. 44, 327, 365, 701 („Cum Magno illo Philosopho Carthesio, Hollandiam, tum cum in Sueciam tenderet transeunte anno 1649 miscui tunc de talibus sermones").

${ }^{69}$ Por. A. Marks, Pod znakiem komety, Katowice 1985, s. 28-29.

${ }^{70}$ Marcello Squarcialupi zetknął się z Braćmi Polskimi przez Andrzeja Dudycza (1533-89), utrzymującego kontakty z Tycho de Brahe. Zob.: K. Głombiowski, W kręgu czytelniczym humanistów wrocławskich, Wrocław 1955, s. 13; J. North, op. cit., s. 205-211; T. Przypkowski, Zainteresowania matematyczno-astronomiczne, s. 393-396, który racjonalistyczną postawę Squarcialupiego uznał za pozbawioną "balastu wizjonerstwa”; S. Lubieniecki, Theatrum cometicum, cz. 2, s. 367, 373.

${ }^{71}$ Por. S. Lubieniecki, Theatrum cometicum, cz. 2, s. 374.

${ }^{72}$ Ibidem, cz. 1, s. 418, 560-561, 605. Powiedzenie to prawdopodobnie pochodzi z listu Bertholda z Regensburga z ok. 1270 r. Zob. I. Berthold von Regensburg, Vollständige Ausgabe seiner Predigten, ed. F. Pfeiffer, Bd. 1, Wien 1862, s. 50.

${ }^{73}$ Julius Firmicus Maternus, De nativitatibus sive Matheseos Libri VIII etc., Francesco Negri, Venezia 1499 (egz. Biblioteki Zgromadzenia Księży Misjonarzy w Krakowie, sygn. 54-III-B). Zob. S. Lubieniecki, Theatrum cometicum, cz. 1, s. 801. 
wyłącznie zjawisk naturalnych - przyrodniczych, nigdy zaś tzw. sfery duchowej człowieka ${ }^{74}$.

Jednakże należy tu stanowczo podkreślić, że Theatrum cometicum nie ma charakteru astrologicznego, a Lubieniecki prezentuje wyraźnie sceptyczny stosunek do samej astrologii, szczególnie tej, którą określa mianem „superstitiosa”, starając się ją wyraźnie oddzielić od nauki ścisłej i wielce pożytecznej, za jaką uważał astronomię $e^{75}$. Po wielekroć jednocześnie arianin, manifestując wiarę w Boga, Jemu właśnie przyznaje moc kreowania rzeczywistości i oddziaływania na czyny ludzkie oraz wszelakie wydarzenia rozgrywające się w świecie podksiężycowym. Podkreślał stanowczo: "Mihi certum est talia non necessario ad Cometas referenda"76. Nieustannie podejmował też działania mające na celu „oswojenie" komet i uzmysłowienie szeroko pojmowanemu społeczeństwu, iż są to fascynujące, podlegające prawom fizyki, acz niezwykle tajemnicze ciała niebieskie. Określał je mianem „nobilissimae caeli phoenomenae”, ,,signi physici certi et determinati", które nie mogą wpływać ani na duszę, ani na wiarę człowieka ${ }^{77}$. Poglądy te starał się poprzeć merytorycznymi i jednocześnie łatwymi do zrozumienia argumentami. Twierdził zatem, iż komety nie są jednakowo widoczne dla wszystkich, a to z powodu położenia horyzontu względem obserwatora. Ogon komety, rozświetlający nocne niebo, w promieniach słońca staje się niewidoczny, co nie znaczy przecież, że komety nie ma ${ }^{78 !}$ W części trzeciej swojego dzieła zawarł nawet ustęp zatytułowany Fundamenta sententiae contra determinatam Astrorum efficientiam et pro indifferenti ac aequa bonis malisque cometarum significatione morali disputantis $^{79}$, w którym przedstawił argumenty podważające wiarę $\mathrm{w}$ determinizm kometarny, słusznie twierdząc, iż: „Cometas semper existere, licet non semper appareant" ${ }^{\prime \prime 0}$. Ponadto, uznał za zasadne przypomnieć, że zarówno przed pojawieniem się komety na nieboskłonie na Ziemi dzieją się różnorakie niepomyślne wydarzenia, podobnie jak po jej ukazaniu się - pomyślne. Zatem „nil certi in alterutram partem determinari

${ }^{74}$ Por. S. Lubieniecki, Theatrum cometicum, cz. 3, s. 31 („Inclinare astra hominem quodammodo, quod ad actiones naturales attinet, pariter non nego: sed eadem voluntatem hominis et ab ea profectas actiones excitare vel dirigere, et in hominum mentes liberas influente vi malefica saevire, cum illa usibus nostris servire iussa sint, ut credam induci non possum").

${ }^{75}$ Por. ibidem, cz. 1, s. 44-45, 571.

${ }^{76}$ Ibidem, cz. 1, s. 633.

77 Por. ibidem, cz. 1, s. 341

${ }^{78}$ Por. ibidem, cz. 1, s. 619 („Cometas non omnes ab omnibus videri posse, horizonti diversis ratio docet. Multorum conspectum eripit nobis etiam vicinum illis lumen Solis").

${ }^{79}$ Por. ibidem, cz. 3, s. 41-43.

${ }^{80}$ Ibidem, cz. 3, s. 42. 
queat" ${ }^{\prime 1}$. Ubolewał przy tym, że każdorazowe pojawienie się komety sprawia, iż wszystko to, co da się zaobserwować, a więc wspomniane „barba, coma, cauda, colore, motu, situ peti solitas" były i nadal są wykorzystywane do celów profetycznych przez astrologów i, co gorsza, upubliczniane $\mathrm{w}$ formie fatalistycznych przepowiedni ${ }^{82}$. Nie omieszkał jednocześnie dodać, że astrologowie, nie wiedzieć czemu, skutków pojawienia się komety doszukują się w odległych czasowo późniejszych wydarzeniach. A przecież, jak czytamy w Theatrum cometicum, "Cometas et alia caeli signa nec timenda, nec temnenda, sed ut industriae et virtutis invitamenta, incitamenta et argumenta esse ducenda" ${ }^{\prime 83}$.

Theatrum cometicum, choć nie znalazło zbyt wielu odbiorców w momencie ukazania się drukiem ${ }^{84}$, za sprawą pojawienia się pod koniec 1680 r. bardzo dużej i jasnej komety ${ }^{85}$ (ze względu na szczególne zainteresowanie i prace badawcze nad nią prowadzone przez Izaaca Newtona, nazywanej „,kometą Newtona" ${ }^{86}$ ), zostało w roku następnym ponownie wypuszczone do sprzedaży jako rzekome wydanie drugie ${ }^{87}$. Willy Ley sugeruje, że w obliczu psychozy, jaka zapanowała na skutek pojawienia się wspomnianej komety, treść, jaką niosło Theatrum cometicum, miała być przejawem zdrowego rozsądku i próbą zapanowania nad paraliżującym strachem przed tymi wyjątkowymi obiektami niebieskimi ${ }^{88}$. Jakże ważne, w tym kontekście, okazywało się przesłanie Lubienieckiego, by komet wespół z innymi znakami pojawiającymi się na nieboskłonie, „,wraz z bezbożnymi nie lekceważyć, wraz z przesądnymi nie obawiać się ani nie oka-

\footnotetext{
${ }^{81}$ Ibidem, cz. 3, s. 42; cz. 1, s. 122.

${ }^{82}$ Ibidem, cz. 1, s. 341-342.

${ }^{83}$ Ibidem, cz. 3, s. 15-16, 42.

${ }^{84}$ Por. J. Tazbir, Stando lubentius moriar, s. 175-179 (o zmaganiach Lubienieckiego z wydaniem i kolportażem dzieła).

${ }^{85}$ Zob.: S. Słowakowic, Postliminium Cometarum, Abo raczey Niebo z Dawna a niestusznie, Kometom przez Filozofow odebrane, a teraz znowu Prawem y wymiarem geometrycznym, z okazyey świecacey w Roku 1680. y 1681. w Grudniu y Styczniu Komety, za Staraniem y nakładem Stanisława Słowakowica Mediciny Doktora y Professora Rayce Krakowkiego z Przydatkiem krotkiego na końcu Prognostyku Przywrocone, Drukarnia Akademicka, Kraków 1681 (egz. BK, sygn. 2 A-14, Mf 6675); K. Krzykawski, Krotka astrologiczna uwaga Komety. Na horyzoncie Krakowskim około ostatnich dni Grudnia powstajacego w Roku Pańskim 1680. ginacego zaś około pierwszych dni Lutego w Roku niniejszym 1681.[...], Woyciech Gorecki J. K. M. Typ., Kraków 1681 (egz. Biblioteki UŁ, sygn. St. Dr. 1011093).

${ }^{86}$ Por. H.W. Elson, Comets. Their Origins, Nature and History, New York 1910, s. 26.

${ }^{87} \mathrm{~W}$ rzeczywistości były to pozostałe egzemplarze pierwszego wydania, w których zmieniono kartę tytułowa, dodano nowe ryciny i zmieniono tytuł części drugiej na Historia universalis omnia cometarum. Zob. A. Brückner, Lubieniecki Stanistaw, s. 796.

${ }^{88}$ Por. W. Ley, W niebo wpatrzeni. Nieoficjalna historia astronomii od Babilonu do ery kosmicznej, tłum. E. Kolińska, B. Orłowski, Warszawa 1984, s. 154.
} 
zywać dla nich pogardy, ani nie traktować podejrzliwie, lecz rozważać, jako pobudki do cnoty" 89 .

Również w XVIII w. to przepełnione rozważaniami natury filozoficzno-teologicznej dzieło, pomimo ewidentnego wkładu $\mathrm{w}$ szerzenie teorii heliocentrycznej, nie było postrzegane jako mające znaczny udział w rozwoju nauk astronomicznych. Jeden z ówczesnych uczonych, jezuita Jan Bohomolec (1724-1795), w swoim prognostyku z 1770 r., przejawiając dosyć krytyczne nastawienie do wszelkich praktyk astrologicznych, podjął próbę ustosunkowania się do determinizmu astrologicznego. Jednakże $\mathrm{w}$ dodatku do swego dzieła zamieścił chronologiczny rejestr komet w zestawieniu z wydarzeniami kojarzonymi z ich pojawieniem się na niebie. Rejestr ten wybiórczo, bez adekwatnego komentarza naukowego, został zaczerpnięty właśnie $\mathrm{z}$ Theatrum cometicum, co przyczyniło się do deprecjacji wartości naukowej dzieła ${ }^{90}$. Znaczenie dzieła docenił jednak jeden z najbardziej znanych selenografów, Johann Schröter, który w 1802 r. imieniem Stanisława Lubienieckiego nazwał 37-kilometrowy krater na Księżycu ${ }^{91}$.

Współcześnie dzieło Lubienieckiego nie jest, a przynajmniej dotąd nie było traktowane $\mathrm{z}$ należytą powaga, aczkolwiek wielokrotnie odwoływali się doń badacze różnych dyscyplin naukowych, z astronomią na czele. George Forbes, pisząc Historie astronomii, przy kwestiach dotyczących komet zauważył: „For a full account of the wonders of the cometary world the reader is referred to books on descriptive astronomy, or to monographs on comets" ${ }^{\prime 92}$. Z kolei Theatrum cometicum określił mianem ",the great work of Lubienietzki", dwukrotnie, dla zobrazowania historii poszczególnych komet, posiłkując się drzeworytami zaczerpniętymi właśnie z tego dzieła ${ }^{93}$. Jan Gadomski uznał, iż właśnie za przyczyną dzieła Stanisława Lubienieckiego młodszego polska astronomia wniosła bardzo poważny wkład do europejskich badań nad kometami, podkreślając jednocześnie znaczenie dzieła dla współczesnych badaczy, identyfikujących raz po

${ }^{89}$ S. Lubieniecki, Theatrum cometicum, cz. 3, s. 42 (,,[...] ut Cometas, aliave signa caeli, nec temnamus cum impiis, nec timeamus cum superstitiosis, nec despiciamus nec suspiciamus, sed ut incitamenta virtutis contemplemur").

${ }^{90}$ Por. J. Bohomolec, Prognostyk zły czy dobry komety z roku 1769 y 1770 albo natura y koniec komet z przydatkiem [...], drukarnia J. K. Mci y Rzeczypospolitey w Kollegium Soc. Jesu R. P., Warszawa 1770 (egz. BUW, sygn. St. Dr. 5.13.4.40, s. 249), s. 1-255. Zob. D. Kowalewska, Magia i astrologia w literaturze polskiego oświecenia, Toruń 2009, s. 70-72.

${ }^{91}$ Por.: A. Marks, Księżyc, Warszawa 1970, s. 76, 94; J. Włodarczyk, Księżyc w nauce i kulturze Zachodu, Poznań 2012, s. 300.

${ }^{92}$ G. Forbes, History of Astronomy, London 1909, s. 122.

${ }^{93}$ A. Guillemin, The World of Comets, trans., ed. by J. Glaisher, London 1877, s. 21, $146,158$. 
raz pojawiające się komety ${ }^{94}$. Wartość dokonań Lubienieckiego dostrzegli również autorzy prac popularyzujących wiedzę na temat komet, dość wymienić Stanisława R. Brzostkiewicza, który, nazywając XVII-wiecznego astronoma „wybitnym uczonym polskim”, przyznał mu właściwe miejsce pośród plejady światłych umysłów XVII w..$^{95}$.

Jednakże, niestety, wiele prac traktujących o historii astronomii w ogóle nie wspomina Theatrum cometicum Stanisława Lubienieckiego, inne ograniczają się do krótkiej, zdawkowej i zazwyczaj mało pochlebnej informacji, nazywając to monumentalne dzieło "mało samodzielną pracą o charakterze kompilacyjnym” bądź też, cytując Henryka Barycza - „dyletanckim" ${ }^{\prime 96}$. Czasami w literaturze przedmiotu możemy napotkać opinie sytuujące Lubienieckiego młodszego w kręgu zwolenników determinizmu kometarnego, ale pojmowanego w sposób szczególny - pozytywny lub negatywny wpływ komet uzależniony jest od natury człowieka: złym pojawienie się komety przynosi nieszczęście, dobrym - szczęście ${ }^{97}$. Niesprawiedliwa wydaje się również opinia Wincentego Karczewskiego, jakoby jedynym celem przyświecającym Lubienieckiemu podczas pisania Theatrum cometicum było udowodnienie, że „nie było wielkich wypadków bez komet, a komet bez wielkich wypadków" ${ }^{\prime 98}$. Opinia ta dziwi tym bardziej, że w tym samym dziele autor przyznał, iż mozolna praca wykonana przez arianina może być przydatna astronomom.

A przecież dzieło to, przywołując słowa cytowanego już wielokrotnie Janusza Tazbira, „,stanowi wyraz tendencji panujących zarówno w barokowej nauce, jak też sztuce i architekturze. [...] Świat przyrody jest dla niego scena, na której historia odgrywa swe dramaty oświetlane błyskami złych i dobrych komet" ${ }^{\prime \prime 9}$. Warto tu przytoczyć również opinię Barbary Bieńkowskiej podkreślającej, że Stanisław Lubieniecki nie był co prawda z wykształcenia astronomem, lecz mimo to okazał się gorącym zwolennikiem nowożytnych tendencji naukowych i w pełni docenił znaczenie teorii heliocentrycznej (wkład dzieła Lubienieckiego w propagowanie teorii heliocentrycznej podkreślił również J. Tazbir) ${ }^{100}$. I choć współcześnie wielu uczonych zdaje się minimalizować znaczenie Theatrum come-

${ }^{94}$ J. Gadomski, Zarys historii astronomii polskiej, Kraków 1948, s. 12. Zob.: J. Sapalski, O kometach i teoryi (sic!) biegu ciat, Warszawa 1843, s. 30; A. Brückner, Dzieje kultury polskiej, t. 2: Polska u szczytu potęgi, Kraków 1930, s. 538.

${ }^{95}$ S.R. Brzostkiewicz, Komety - ciała tajemnicze, Warszawa 1985, s. 17-19.

${ }^{96}$ M. Iłowiecki, Dzieje nauki, s. 79; H. Barycz, Barok, s. 116.

${ }^{97}$ Por. M. Ernst, O końcu świata i kometach, Warszawa ok. 1910, s. 18.

${ }^{98}$ W. Karczewski, O kometach, Wilno 1826, s. 40, 99.

${ }^{99}$ J. Tazbir, Stando lubentius moriar, s. 175.

${ }^{100}$ B. Bieńkowska, Kopernik, s. 163; J. Tazbir, Stanisław Lubieniecki-przywódca ariańskiej emigracji, s. 267. 
ticum dla rozwoju nauki, to jednak nie sposób nie docenić wielkiego wysiłku, jaki podjął jego autor, wysiłku tym bardziej godnego uwagi, że Lubieniecki, jak już wspomniałam, nie miał wykształcenia astronomicznego! Znakomitą pointą niech będzie opinia poety Józefa Andrzeja Załuskiego (1702-1774), wychowanka kolegiów jezuickich i pijarskich, który w wierszu O kometach napisał:

Chceszli wiedzieć z początku świata kiedy, jaka

Zjawiła się kometa, to czytaj Polaka

Theatrum cometicum, księgę Stanisława

Lubienieckiego (szkoda, że był policzony w liczbie socinianów, ale był uczony) ${ }^{101}$.

BIBLIOGRAFIA

\section{Źródła}

Berthold von Regensburg, Vollständige Ausgabe seiner Predigten, Bd. 1, ed. F. Pfeiffer, Wien 1862.

Bohomolec J., Prognostyk zty czy dobry komety z roku 1769 y 1770 albo natura y koniec komet z przydatkiem [...], drukarnia J. K. Mci y Rzeczypospolitey w Kollegium Soc. Jesu R.P., Warszawa 1770 (egz. BUW, sygn. St. Dr. 5.13.4.40, s. 249).

Brożek J., Wybór pism, t. 1-2, oprac. H. Barycz (t. 1), J. Dianni (t. 2), Warszawa 1956.

Estreicher K., Bibliografia polska, t. 21: Stólecie XVI-XVIII, Kraków 1906; t. 29, Kraków 1933.

Fletcher J.E., A Study of the Life and Works of Athanasius Kircher, "Germanus Incredibilis". With a Selection of His Unpublished Correspondence and an Annotated Translation of His Autobiography, Leiden 2011.

Franke J.N., Jan Brożek (J. Broscius) akademik krakowski 1585-1652. Jego życie i dzieła, ze szczególnem uwzględnieniem prac matematycznych. Ze źródet rękopiśmiennych, Kraków 1884.

Gadbury J., De Cometis, or, A Discourse of the Natures and Effects of Comets as they are Philosophically, Historically, and Astrologically Considered, by L. Chapman, London 1665.

Hevelius J., Cometographia, totam naturam cometarum [...] nee non motum eorum summae admirandum, Simon Reiniger, Gedani 1668 (egz. Biblioteka Śląska, Katowice, sygn. St. Dr. 225097 IV).

Julius Firmicus Maternus, De nativitatibus sive Matheseos Libri VIII etc., Francesco Negri, Venezia 1499 (egz. Biblioteki Zgromadzenia Księży Misjonarzy w Krakowie, sygn. 54-III-B).

Kopernik M., Dzieła wszystkie, t. 2: O obrotach, tłum. M. Brożek, S. Oświęcimski, kom. A. Birkenmajer, J. Dobrzycki, red. J. Dobrzycki, Warszawa-Kraków 1976.

Krzykawski K., Krotka astrologiczna uwaga Komety. Na horyzoncie Krakowskim około ostatnich dni Grudnia powstającego w Roku Pańskim 1680. ginacego zaś około pierwszych dni Lutego w Roku niniejszym 1681. [...], Woyciech Gorecki J. K. M. Typ., Kraków 1681 (egz. Biblioteki UŁ, sygn. St. Dr. 1011093).

Księga wpisów Gimnazjum Gdańskiego (1580-1814), oprac. Z. Nowak, P. Szafran, Warszawa 1974.

Lubieniecki S., Historia Reformationis Polonicae, ed. H. Barycz, Varsoviae 1971.

${ }^{101}$ Filozofia i myśl społeczna w latach 1700-1830, t. 1: Okres saski 1700-1763, red. i wstęp

M. Skrzypek, Warszawa 2000, s. 272. 
Lubieniecki S., Theatrum cometicum, cz. 1-3, Typis Danielis Baccamude, apud Franciscum Cuperum, sumptibus authoris, Amstelodami 1666-1668 (egz. Biblioteki Muzealnej im. Przypkowskich w Jędrzejowie, sygn. S. 199).

Milton J., Raj utracony, tłum. M. Słomczyński, Warszawa 1974.

Myśl ariańska w Polsce XVII wieku. Antologia tekstów, wybór, oprac., wstęp i noty Z. Ogonowski, Wrocław-Warszawa-Kraków 1991.

Ogonowski Z., Dwa listy Wiszowatego do S. Lubienieckiego, „,Studia i Materiały z Dziejów Nauki Polskiej" 1956, 4.

Słowakowic S., Postliminium Cometarum, Abo raczey Niebo z Dawna a niestusznie, Kometom przez Filozofow odebrane, a teraz znowu Prawem y wymiarem geometrycznym, z okazyey świecacey w Roku 1680. y 1681. w Grudniu y Styczniu Komety, za Staraniem y nakładem Stanistawa Stowakowica Mediciny Doktora y Professora Rayce Krakowkiego z Przydatkiem krotkiego na końcu Prognostyku Przywrocone, Drukarnia Akademicka, Kraków 1681 (egz. BK, sygn. 2 A-14, Mf 6675).

Trembecki J.T., Wirydarz poetycki, t. 1, wyd. A. Brückner, Lwów 1910.

Żebrawski T., Bibliografija (sic!) piśmiennictwa polskiego z dziatu matematyki i fizyki oraz ich zastosowań, Kraków 1873.

\section{Opracowania}

Barański L., Hintz M. bp, Sojka J., Reformatorzy, Bielsko-Biała 2013.

Barycz H., Barok, w: Historia nauki polskiej, t. 2, wstęp, red. B. Suchodolski, Wrocław-Warszawa-Kraków 1970.

Barycz H., Jan Brożek na tle walki elementów postępowych z tradycyjnymi na Uniwersytecie Krakowskim, Kraków 1954.

Barycz H., Stanisław Lubieniecki jako historyk reformacji, w: Wokót dziejów i tradycji arianizmu, red. L. Szczucki, Warszawa 1971.

Barycz H., Z dziejów polskich wędrówek naukowych za granicę, Wrocław 1969.

Bibliografia Literatury Polskiej. Nowy Korbut, red. K. Budzyk, Piśmiennictwo staropolskie, cz. 2, oprac. R. Pollak, Warszawa 1964.

Bieńkowska B., Kopernik i heliocentryzm w polskiej kulturze umysłowej do końca XVIII w., Wrocław 1971 (Studia Copernicana, t. 3).

Brodnicki M., Program edukacji przyrodniczej w okresie pobytu Jana Heweliusza w Athenae Gedanenses, w: Jan Heweliusz i kultura heweliuszowska. Utilitas et delectatio, Gdańsk 2013.

Brückner A., Dzieje kultury polskiej, t. 2: Polska u szczytu potęgi, Kraków 1930.

Brückner A., Lubieniecki Stanistaw, w: Wielka encyklopedya powszechna ilustrowana, t. 43-44, Warszawa 1910.

Brzostkiewicz S.R., Komety - ciała tajemnicze, Warszawa 1985.

Burns W.E., An Age of Wonders. Prodigies, Politics and Providence in England 1657-1727, New York 2002.

Chmaj L., Bracia Polscy. Ludzie, idee, wptywy, Warszawa 1957.

Chmaj L., Jan Placentinus-Kołaczek, nieznany kartezjanin XVII wieku, „Archiwum Historii Filozofii i Myśli Społecznej" 1957, 1.

Chmaj L., Kartezjanizm w Polsce w XVII i XVIII wieku, „Myśl Filozoficzna” 1956, 5.

Chmaj L., Samuel Przypkowski na tle prądów religijnych XVII w., Kraków 1927.

Cummins J., Milton and the Ends of Time, Cambridge 2003.

Cynarski S., Znajomość nauki Kopernika w Polsce XVII i XVIII wieku Kraków 1973.

Defoe D., Landa A., A Journal of the Plague Year, Oxford 1998.

Dobrzycki J., Markowski M., Przypkowski T., Historia astronomii w Polsce, t. 1, red. E. Rybka, Wrocław-Warszawa-Kraków-Gdańsk 1975. 
Dworzaczek W., Schlichtingowie w Polsce. Szkice genealogiczno-historyczne, Warszawa 1938.

Elson H. W., Comets. Their Origins, Nature and History, New York 1910.

Ernst M., O końcu świata i kometach, Warszawa ok. 1910.

Filozofia i myśl społeczna w latach 1700-1830, t. 1: Okres saski 1700-1763, red. i wstęp M. Skrzypek, Warszawa 2000.

Filozofia i myśl społeczna XVII wieku, cz. 2, wybór, oprac. i wstęp Z. Ogonowski, Warszawa 1979.

Forbes G., History of Astronomy, London 1909.

Gadomski J., "Theatrum Cometicum” Stanistawa Lubienieckiego, „Urania” 1954, 25, 6.

Gadomski J., Zarys historii astronomii polskiej, Kraków 1948.

Geneva A., Astrology and the Seventeenth Century Mind. William Lilly and the Language of the Stars, Manchester 1995.

Głombiowski K., W kręgu czytelniczym humanistów wrocławskich, Wrocław 1955.

Gołaszewski Z., Bracia Polscy, Torun 2004.

Grycz-Śmiłowski K., Bracia Polscy. Arianie - unitarianie. Zarys dziejów i nauki, Kraków 1948.

Guillemin A., The World of Comets, trans., ed. by J. Glaisher, London 1877.

Hazard P., Kryzys świadomości europejskiej 1680-1715, tłum. J. Lalewicz, A. Siemek, wstęp M. Żurowski, Warszawa 1974.

Iłowiecki M., Dzieje nauki polskiej, Warszawa 1981.

Karczewski W., O kometach, Wilno 1826.

Koestler A., Lunatycy. Historia zmiennych pogladów człowieka na wszechświat, tłum. T. Bieroń, Poznań 2002.

Konarska S., Lubieniecki Stanisław młodszy, w: Świętokrzyski słownik biograficzny, t. 1: Do 1795 r., Kielce 2002.

Konarska S., Wiszowaty Andrzej, w: Świętokrzyski słownik biograficzny, t. 1: Do 1795 r., Kielce 2002.

Kot S., Oddziaływanie Braci Polskich zwanych socynianami w Anglii, w: S. Kot, Polska złotego wieku a Europa. Studia i szkice, wybór i wstęp H. Barycz, Warszawa 1987.

Kowalewska D., Magia i astrologia w literaturze polskiego oświecenia, Toruń 2009.

Kubik K., Mokrzecki L., Trzy wieki nauki gdańskiej. Szkice z dziejów od XVI do XVIII w., Wrocław-Gdańsk 1976.

Kurdybacha Ł., Z dziejów pedagogiki ariańskiej, Warszawa 1958.

Leśniak K., Poglady naukowe Franciszka Bacona, „,Kwartalnik Historii Nauki i Techniki” 1961, $6,3$.

Ley W., W niebo wpatrzeni. Nieoficjalna historia astronomii od Babilonu do ery kosmicznej, tłum.

E. Kolińska, B. Orłowski, Warszawa 1984.

Ławrynowicz K., Albertina. Szkice z dziejów Uniwersytetu Królewieckiego, wstęp Z. Pietrzyk, tłum. J. Leszczyńska, Kraków-Pułtusk 2010.

Marks A., Księżyc, Warszawa 1970.

Marks A., Pod znakiem komety, Katowice 1985.

Nadolski B., Walka o myśl Kopernika i losy jej w Polsce, w: Wkład Polaków do nauki. Nauki ścisłe. Wybór artykułów, wybór, oprac., przedm. J. Hurwic, Warszawa 1967.

North J., Historia astronomii i kosmologii, tłum. T. Dworak, Katowice 1997.

Nowicki A., Kościół przeciwko Kopernikowi, „Myśl Filozoficzna” 1953, 1.

Ogonowski Z., Racjonalizm w polskiej myśli ariańskiej i jego oddziaływanie na Zachodzie, „Odrodzenie i Reformacja w Polsce" 1956, 1.

Ogonowski Z., Socynianizm polski, Warszawa 1960.

Orchard T.N., Milton's Astronomy. The Astronomy of "Paradise Lost", London 1913. 
Pelc J., Rola i znaczenie pisarzy ariańskich w literaturze polskiej XVII wieku, w: Wokót dziejów i tradycji arianizmu, red. L. Szczucki, Warszawa 1971.

Przypkowski P.M., Zaczkowski R., Zbiory Muzeum im. Przypkowskich w Jęrzejowie, Jędrzejów 2012.

Przypkowski T., Dzieje myśli kopernikowskiej, Warszawa 1954.

Przypkowski T., Pierwsze poprawne widoki Jowisza i Saturna z r. 1664 ogłoszone przez Stanisława Lubienieckiego, „Sprawozdania z Czynności i Posiedzeń Polskiej Akademii Umiejętności" 1951, 52, 6.

Przypkowski T., Zagadnienia astronomiczne w autografach Stanisława Pudłowskiego, "Studia i Materiały z Dziejów Nauki Polskiej" Seria C. Historia nauk matematycznych, fizyko-chemicznych i geologiczno-geograficznych 1967, 12.

Przypkowski T., Zainteresowania matematyczno-astronomiczne Braci Polskich, w: Studia nad arianizmem, red. L. Chmaj, Warszawa 1959.

Przypkowski T., Z dziejów heliocentryzmu w Polsce, „Myśl Filozoficzna” 1953, 1.

Rybka E., Heweliusz Jan, w: Polski Stownik Biograficzny 1960-1961, 9.

Salmonowicz S., Nauczanie filozofii w toruńskim gimnazjum akademickim (1568-1793). Organizacja, wykładowcy, podręczniki, w: Nauczanie filozofii w Polsce w XV-XVIII wieku. Zbiór studiów, red. L. Szczucki, Wrocław 1978.

Sapalski J., O kometach i teoryi (sic!) biegu ciat, Warszawa 1843.

Schechner S.J., Comets, Popular Culture, and the Birth of Modern Cosmology, Princeton-New Jersey 1997.

Stephen L., Lee S., Dictionary of National Biography, t. 20, New York 1889.

Targosz K., Jan Heweliusz uczony - artysta, Wrocław-Warszawa-Kraków-Gdańsk-Łódź 1986.

Tazbir J., Ideologia arian polskich, Warszawa 1956.

Tazbir J., Lubieniecki Stanisław młodszy, w: Polski Słownik Biograficzny 1972, 17.

Tazbir J., Recepcja polskiego przekładu "Relazioni Universali”, „Kwartalnik Historii Nauki i Techniki" 1990, 35, 2-3.

Tazbir J., Reformacja w Polsce. Szkice o ludziach i doktrynie, Warszawa 1993.

Tazbir J., Stando lubentius moriar. Biografia Stanisława Lubienieckiego, Warszawa 2003.

Tazbir J., Stanisław Lubieniecki, przywódca ariańskiej emigracji, Warszawa 1961.

The Reception of Copernicus' Heliocentric Theory. Proceedings of a Symposium Organized by the Nicolas Copernicus Committee of the International Union of the History and Philosophy of Science, Toruń, Poland 1973, ed. by J. Dobrzycki, Boston 1973 (Studia Copernicana 5).

Tync S., Dzieje gimnazjum toruńskiego, cz. 1-2, Toruń 1927-1949.

Tync S., Wyższa szkoła braci polskich w Rakowie. Zarys jej dziejów (1602-1638), w: Studia nad arianizmem, red. L. Chmaj, Warszawa 1959.

Tync S., Zarys dziejów wyższej szkoły braci polskich w Rakowie, w: Raków ognisko arianizmu, red. S. Cynarski, Kraków 1968.

Urban W., Losy Braci polskich od założenia Rakowa do wygnania z Polski, w: Et haec facienda, et illa non omittenda. Profesor Wactaw Urban w swych dziełach wybranych, red. A. Kądziela, W. Kowalski, J. Muszyńska, Z. Pietrzyk, Warszawa 2012.

Wasiutyński J., Kopernik. Twórca nowego nieba, Torun 2007.

Wąsik W., Kartezjusz w Polsce, „Przegląd Filozoficzny” 1937.

Włodarczyk J., Dodatek: Astronomia w Polsce, w: Historia astronomii, red. M. Hoskins, tłum. i wyd. J. Włodarczyk, Warszawa 2007.

Włodarczyk J., Księżyc w nauce i kulturze Zachodu, Poznań 2012.

Włodarczyk J., Księżyc w nauce XVII wieku. Libracja: od astronomii do astrofizyki, Warszawa 2005. 
Wydrych-Gawrylak M., Gwiazdarze i horoskopy, słońca, gwiazdy, księżyce oraz akcesoria astronomiczne, czyli staropolskie fascynacje niebieskie, w: Poezja i astronomia, red. B. Burdziej, G. Halkiewicz-Sojak, Torun 2006.

Yeomans D.K., Komety. Od starożytności do współczesności, w mitach, legendach i nauce, tłum. A.S. Pilski, Warszawa 1999.

Zins H., Mikołaj Kopernik w angielskiej kulturze umysłowej epoki Szekspira, Wrocław-Warszawa-Kraków-Gdańsk 1972.

Żołądź-Strzelczyk D., Peregrinatio academica. Studia młodzieży polskiej z Korony i Litwy na akademiach i uniwersytetach niemieckich w XVI i 1 poł. XVII wieku, Poznań 1996.

\begin{abstract}
The Polish Brethren called "Arians" and "Socinians" were members of the Minor Reformed Church of Poland that existed in Poland from 1565 to 1658. Their biggest cultural center was Raków. There was the Racovian Academy founded in 1602 and closed in 1638. The Racovian students were taught Latin, ethics, rhetoric, mathematics, politics and natural science (e.g. cosmology). One of the most prominent representatives of the Racovian Academy was Stanisław Lubieniecki the Younger. He wrote very important work about comets -- Theatrum cometicum, parts 1-3 (1666-1668), in which he described 415 comets from the biblical epoch of the deluge up until 1665. This work is also an interpretation of his views on the so-called cometary determinism. Thanks to Theatrum cometicum, Stanisław Lubieniecki the Younger deserved to be called an "astronomer" although he did not receive astronomical education.
\end{abstract}

Key words: Arians, astronomy, astrology, comets, determinism

\title{
NOTA O AUTORZE
}

Sylwia Konarska-Zimnicka - adiunkt w Zakładzie Historii Średniowiecznej Instytutu Historii Uniwersytetu Jana Kochanowskiego w Kielcach. Zainteresowania badawcze: historia kultury późnośredniowiecznej i wczesnonowożytnej, historia Kościoła, życie codzienne w wiekach średnich, taniec, muzyka i inne formy zabawy w wiekach średnich, rozwój nauki średniowiecznej i wczesnonowożytnej, ze szczególnym uwzględnieniem medycyny, astronomii, astrologii, piśmiennictwo średniowieczne, nauki pomocnicze historii, przede wszystkim edytorstwo źródeł i paleografia średniowieczna. 